\title{
Becoming Mobile: Reference in the Ubiquitous Library
}

\author{
Frederick D. Barnhart \\ Loyola University Chicago, fbarnha@luc.edu \\ Jeannette E. Pierce \\ Loyola University Chicago, jpierc2@luc.edu
}

Follow this and additional works at: https://ecommons.luc.edu/lib_facpubs

Part of the Educational Assessment, Evaluation, and Research Commons, Instructional Media Design Commons, and the Library and Information Science Commons

\section{Recommended Citation}

Barnhart, Fred D. and Pierce, Jeannette E.(2011) 'Becoming Mobile: Reference in the Ubiquitous Library', Journal of Library Administration, 51: 3, $279-290$

This Article is brought to you for free and open access by the Faculty Publications and Other Works by Department at Loyola eCommons. It has been accepted for inclusion in University Libraries: Faculty Publications and Other Works by an authorized administrator of Loyola eCommons. For more information, please contact ecommons@luc.edu.

\section{(c) $\odot \ominus$}

This work is licensed under a Creative Commons Attribution-Noncommercial-No Derivative Works 3.0 License. 
Becoming Mobile: Reference in the Ubiquitous Library

Fred D. Barnhart

Jeannette E. Pierce

Loyola University Chicago 


\begin{abstract}
Our library patrons are adopting mobile devices for personal and other uses. The ubiquity of mobile devices will lead to changes in how and where learning and education happens. Libraries have wanted to become ubiquitous by making resources and services available anytime, anywhere. Reference librarians can use mobile devices and applications to include services in mobile learning environments. Challenges to libraries include uncertainty about which technologies to adopt in rapidly changing technology landscape, cost of technology adoption, staffing for 24/7, diversity of needs and preferences among library patrons, and the need to offer stable, consistent services. The combination of mobile librarians, mobile patrons, and mobile content is an opportunity to move closer to the ideal of the ubiquitous library.

Keywords: mobile, devices, computing, learning, education, reference, patrons
\end{abstract}


The increasing use of mobile devices, meaning those that are networked, portable, and hand-held, is already having an impact on higher education and academic libraries are responding in a variety of ways, such as by creating mobile web sites and adding text messaging reference services. Some vendors have responded as well, by providing tools and content that can be used with mobile devices. With the trend toward mobile learning in higher education likely to continue, additional developments in mobile computing devices may lead to new types of learning, research, and instruction. It is vital that reference librarians prepare for the unique challenges and opportunities that will come from the combination of mobile patrons, mobile content, and increasingly mobile librarians.

Mobile computing devices are expected to fundamentally change the way all of us communicate because they allow for information retrieval and a variety of communication options on a single device. Lippincott (2010) in her article about the mobile future for academic libraries notes "As smartphones become our users' key information devices, libraries will want to have a significant presence in offering content and services suitable for those devices" (p. 205). In reference to the "m-library," Hahn (2008) writes that "Mobile devices are an opportunity for crafting new library services such as in-library exploration, social engagement, and outreach to traditionally underserved populations, as well as micro-instruction and learning" (p. 84).

The Mobile Access 2010 Report shows that 2 in 5 adults use the internet, e-mail, or IM using a mobile device, which is an increase to $40 \%$, up from $32 \%$ in 2009 . Growth in use of non-voice applications for mobile devices has grown significantly in recent years, especially among young adults and $30-49$ year olds. In fact, $95 \%$ of cell phone owning $18-29$ year olds use text-messaging and young adults in general are significantly more likely to use their cell 
phones for other mobile data applications, such as taking pictures, sending e-mail or accessing the Internet (Smith, 2010).

Many higher education technology reports are also anticipating the continued importance of mobile devices for students. Institutional survey reports such as Informing Innovation (2009) at Ohio University and University of Minnesota’s Twin Cities' $21^{\text {st }}$ Century Students:

Technology Survey (2009) found that large majorities of students now own hand-held or portable devices such as laptops, cell phones, and iPods (Booth; Walker). The University of Minnesota study found that the percentage of students who own or aspire to own smart phones jumped dramatically from 2007 (Walker, 2009). The ECAR Study of Undergraduate Use of Information Technology (2009) found that "About half of the respondents $(51.2 \%)$ indicated they own an Internet-capable handheld device, and another $11.8 \%$ said they plan to purchase one in the next 12 months" (Smith, et al. 2009). Further, the ECAR survey indicated that nearly two thirds of administrators understand that mobile devices with internet capability will become essential tools for higher education (Pirani and Sheehan, 2009). Finally, the Academic College and Research Libraries' (ACRL) Research and Planning Review Committee (2010) cite the "explosive growth of mobile devices and applications" as a driver of new services for academic libraries (p. 288).

Studies on the information seeking behavior of college students suggest that our patrons value convenience and efficiency, often aided by technology, as among the most important factors in how they pursue an information need. The Digital Information Seeker Report by Connaway and Dickey (2010) identified that a common finding across eight significant studies of user behavior was a desire for speed and convenience in addressing information needs. One of the studies, Seeking Synchronicity, by Radford and Connaway (2008), focused specifically on 
virtual reference services and found that users consider convenience to be one of the most important factors in choosing to use a virtual reference service. The challenge for reference services is to leverage mobile technology in order to create convenient, accessible point-of-need services for our users.

The Oxford English Dictionary (OED) defines ubiquitous (n.d.) as "Present or appearing everywhere; omnipresent." While omnipresent may sound overreaching, the ideal of being present where our users are working is a common theme in academic reference literature. In his article on the ubiquitous library, Kaske (2004) suggests that "successful academic libraries will look to provide high quality and timely services where ever our users happen to be" (p. 296). Reference librarians are the public face of many of the personalized services offered by libraries, but in order for those services to become ubiquitous they must become more present at the patron's point of need.

Reference Work is defined as "reference transactions and other activities that involve the creation, management, and assessment of information or research resources, tools, and services" (Reference and User Services Association [RUSA], 2008). Thus, there are two distinct aspects to reference work. One is more synchronous, and focused on the transaction, usually in the form of a question initiated by a patron with an information need. The second, and more asynchronous aspect, is the management and creation of guidance or instructional tools that help patrons use information resources independently. Inherent in both is a need to make these services visible and accessible when and where our patrons need them. If academic libraries are serious about becoming ubiquitous we must continue to explore how new technologies, such as mobile computing, can help make our interpersonal services, our guidance and instructional tools, and our information resources available where they are needed, anytime and anywhere. 
The dominant model of reference service in the $20^{\text {th }}$ century was that of the reference desk. With the development of internet browser applications in the mid-1990s reference librarians expanded the model to include services such as e-mail reference, web-based subject guides, and online tutorials. The 1990 s also saw the wider use of online course management systems leading librarians to look for ways to include relevant library content directly into course pages. Within the last decade reference librarians have adopted chat technologies allowing for more synchronous services such as virtual reference. Lately, as text messaging is becoming more commonplace among patrons, many libraries are exploring ways in which to use texting to offer reference services as well.

Even as reference librarians use technology to reach out to patrons in new ways, there remain concerns about the quality of online reference services as opposed to the in-person services provided at a reference desk. These concerns have led reference librarians to expand opportunities for in-person communication with patrons outside the library. Some examples include embedding librarians into courses or programs, providing roving reference, offering librarian "office hours" in departments, and positioning reference librarians in cafes, residence halls, or other locations where patrons are likely to be working.

Mobile computing technologies may ultimately offer reference librarians the opportunity to re-integrate important elements of in-person communication into our digital reference services by allowing for services based on video communication, as well as providing new ways to share content with our patrons. In addition, reference librarians may be able to use mobile technologies to increase the success of roving and embedded reference models. The combination of users with mobile devices, librarians with mobile devices, and content that is accessible on 
mobile devices will allow reference librarians to further their contributions to the ideal of the ubiquitous library by offering us new ways to be present in the research lives of our patrons.

Appropriately placed into a patron's work environment, digital reference services such as chat/IM or SMS/Text services do meet our patrons need for convenience. However, there are still serious concerns among reference librarians about the quality of digital reference transactions and the ability of these services to assist with complex questions. In particular, reference librarians are concerned about the loss of many verbal, tonal and physical cues that have long allowed for skilled reference librarian to modify or adjust a response to a user. There is a valid argument that digital reference services, whether text or chat, limit the ability of reference librarians to respond well to complex questions, in regards to conducting the reference interview, providing multi-faceted responses, and in ensuring that responses are received and understood. Unfortunately, our patron's desire for convenience, rapid advances in mobile computing, and the expected growth of mobile learning in higher education suggest that forcing users to choose between convenient online services and less convenient, but higher quality, inperson services is a false dichotomy. Instead, reference librarians must continuously look to technology for ways to improve the quality of the digital reference experience. As Bell remarked, "Certainly they [the user] want good service, but not necessarily at the cost of spending face time with a librarian" (Watstein \& Bell, 2008, p. 3).

As wireless access and mobile computing become increasingly ubiquitous, it is reasonable to expect that there will be opportunities for reference librarians to improve virtual reference. For example, screen sharing capabilities will continue to improve as more people are connected to internet data services and consumers demand more interoperability between devices and systems. New software applications will allow librarians to enhance existing services by 
making them more instructional and interactive. One example is that of reference librarians using screen capture tools, such as Jing, to create instructional screen casts on the fly that can be sent to a patron in response to a virtual reference question. Steiner (2010) discusses what can be done with a variety of freely available tools for screen-casting and screen-sharing. More and more vendors are also offering mobile platforms that will allow for librarians to easily share content with our users on their mobile devices. The 2010 Horizon Report identifies electronic books as a key technology to watch, in part because of the advances in mobile reading devices, but also because of the greater availability of content (Johnson, Levine, Smith, \& Stone, 2010).

Video communication tools, such as Skype, are being used for professional communications in both higher education and industry, and have already been piloted as reference tools by some libraries. For example, Booth (2008) writes about Ohio University’s experiments with creating a Skype based reference service. Apple's latest mobile device, the iPhone 4, with its FaceTime video communication application suggests that video communication may soon become widely available on mobile platforms. FaceTime allows two iPhone callers to not only hear each other, but to also see each other, something which has until recently been reserved for communication devices in science fiction settings. Over time, tools that allow for sharing data interactively and a face-to-face interaction will help to address many of the concerns about the quality of digital reference services.

Video communication technology is perhaps not pervasive enough to fully understand the service possibilities, or limitations. Even though video communication technologies may offer an elegant solution to the problems associated with virtual reference services, it is too early to be certain if this will be a service desired by our patrons. Booth (2008) noted that patrons may not find video communication services as appealing as librarians might hope. Reference librarians 
may be projecting our value for interacting face-to-face onto our patrons. Furthermore, as MIT Professor Sherry Turkle comments about Skype in a recent article, people may actually prefer asynchronous communication to live video communication, or even talking by phone in real time. "We want to TiVo our lives, avoiding real time by texting or e-mailing people when we feel like it." (Turkle, as quoted by Stein, 2010, p. 2)

Whether or not our patrons want to see each other, let alone the reference librarian, it seems more important that reference librarians strive to offer what we know the patrons want; control over when and how the reference interaction will occur. One possibility is our patrons will come to desire face-to-face reference service only once they are certain that their information need has reached a level of complexity that demands a high level of their attention.

As relates to convenience and efficiency, reference librarians must continue to explore ways to provide $24 / 7$ reference services. Offering a 24/7 service is among the most important challenges for libraries that want to become ubiquitous in the lives of their patrons. Few libraries have the staffing to manage this on their own which has led many libraries to create consortial arrangements for digital reference service. For example, the Association of Jesuit Colleges and Universities (AJCU) partner to provide a 24/7 virtual reference service. Over 2200 libraries participate in OCLC's QuestionPoint virtual reference service, with over 1400 in the 24/7 Reference Cooperative. (“OCLC's Question Point for Mobile Reference,” 2010) “My Info Quest" is a pilot project in which 36 libraries share the load and collaborate to offer text messaging reference services, with an eventual goal of 24/7 service. (“My Info Quest,” n.d.)

At the same time as librarians have tried to meet expectations for online services, they have also worked to increase opportunities for in-person interaction by offering reference services in multiple locations and by creating robust instructional services. The idea of the 
roving or embedded librarian regularly appears in the literature as a potential alternative to sitting behind a desk and passively waiting for patrons to approach with questions, or even waiting for a virtual reference question. In the roving reference model librarians move around within library spaces, and even some non-library spaces, with the goal of being visible and thus more available to answer reference questions where the patrons are working. Beyond roving, the embedded librarians seek to become more integrated into regular class meetings and projects, creating a closer connection with patrons. From a practical perspective, most of our in-person services can only be offered selectively as it will never be reasonable to expect our staffing levels to support them anywhere, anytime.

Targeted instructional services remain important for their potential to provide patrons with the skills they need to work independently. Lippincott (2010) and Murray (2010) both discuss the potential for mobile devices to personalize learning, and provide point of need instruction. Murray (2010) discusses the use of podcasts and video casts extensively, noting a number of libraries that have been successfully incorporating these tools into their instructional services. Beyond creating instructional content, Lippincott (2010) discusses some of the new ways in which librarians may be able to apply their already existing instructional skills to a mobile learning environment. She includes teaching students how to access information from their mobile devices while in the field, developing mash-ups using geographic applications, and organizing information on their smartphones. Lippincott (2010) reminds us that to be part of the mobile learning environment librarians require an "awareness of innovative assignments, outreach to faculty, and the skills to teach these technologies" (p. 210).

Readily available options to connect to wireless services and increasingly sophisticated portable devices such as netbooks, tablets and the iPad may ultimately allow for more successful 
implementations of roving and embedded librarian service models. In addition to allowing for online communication via IM and chat, these devices allow librarians to have a variety of electronic resources at hand, as well as important assessment tools, such as those for statistics gathering. Imagine the benefit of a librarian able to move from location to location without losing access to any of their important resources and being able to bring these tools up on a screen and share them with library users wherever they are located at the moment. The librarian is also in touch with other librarians and perhaps logged onto digital reference services creating the possibility being available for referrals to other locations or moving about to locations as a means to answer a question online.

Other wireless communication technologies, such as those which use voice communication, are also being piloted in some libraries. Vocera, which began primarily as a communication tool for the healthcare industry, is a wearable, wireless device which allows for instant voice communication with staff members at other locations. Vocera can also connect with the regular telephone system allowing staff to place and receive telephone calls from any location. The Orange County (Florida) Library System is utilizing Vocera and hand-held computers to provide innovative reference services that allow for the librarian to be called to a patron's point-of-need (Robinson, 2005).

It is important for reference librarians to explore ways in which wireless and mobile technologies can extend in-person services, such as roving or embedded librarians, as we strive to make our libraries' services more ubiquitous. In his article on mobile learning and libraries, Hahn (2008) comments, "For our highly scheduled, commodified, pressured students, there exists a need for any time anywhere information - structured information that is organized and accessible. This is surely the domain of the librarian; better yet, the librarian qua teacher" (p. 
273). Reference librarians need to continue to explore how to create, manage, and provide reference transaction tools, such as texting services, that work well on mobile devices. At the same time, it will also be important to develop subject guides, course guides, and other types of online guidance tools for use on mobile computing devices. As we develop the services and tools, reference librarians will need to continue efforts to embed these tools into the work environment of faculty and students through inclusion on course syllabi, within web-based course environments, or as part of specific assignments.

There are a number of challenges for academic libraries in keeping up with the mobile technology trends and patrons' expectations. Each business cycle brings with it new entries to the mobile device market and while iPhone was a strong leader in terms of the number of applications or "apps," and market penetration, the Android OS based mobile devices are rapidly grabbing a share of the market. In addition e-reader devices, such as Kindle, Sony Reader, and Nook, not to mention others, are aggressively seeking a share of the higher education market, and are also beginning to use wireless technology to connect to content. The introduction of the iPad has made likely a whole other group of mobile devices; those with larger touch screens for finer and more detailed touch interaction, possibly supplanting the laptop or netbook market. The list of mobile devices with internet capability that are seeking to grab a share of the market makes it impractical for library staff to create separate solutions for each device. Instead, the goal should be to create scalable and flexible services and resources that will work for a wide variety of mobile devices.

As reference librarians seek to meet patrons in the spaces where they are working, we also need to be cognizant of their diversity and the ways in which it might impact their expectations. As noted earlier, not only do generations adopt and use mobile technology 
differently, patrons of different ethnicity or gender may vary in terms of comfort levels and expectations. By surveying students at Penn State, Abington, Hudson (2010) was able to identify patterns of both expectations and use related to gender and ethnicity. For instance, within the survey's respondents, males of all ethnicities were more likely than females to use live messaging and texting services. The author also referred to Pew studies which showed that a higher percentage of African Americans and Hispanics have used the Internet on handheld devices than White Americans. She concludes by emphasizing the importance of taking into consideration cultural diversity as a factor when providing mobile device based reference services (Hudson, 2010).

If we apply Moore's Law to mobile technology, it is entirely reasonable to expect that mobile devices will continue to advance and some of these advances will help reference librarians improve the quality of online reference transactions. However, the technology may not be able to fulfill the promises of the marketing. Glueck (2010) notes that limitations in terms of batteries and bandwidth, especially if we are depending on video communication over mobile devices, may pose challenges to helping us bridge the gap between the physical reference desk and the ubiquitous library. This reality also argues for the continued existence of a range of virtual reference services, as patrons may view a video reference transaction on a mobile device as battery-draining and as equally unappealing as a trek to the physical reference desk.

The costs of integrating new technology into services can become burdensome. While reference librarians were fairly quick to adopt e-mail and chat services, many of the mobile services described in this article are still in their infancy and may not be as quickly adopted. Not all libraries have been able to absorb the cost of providing 24/7 digital services, even the shared costs of a consortial service can challenge local budgets. For some institutions there 
may be hesitation to apply funds and staff time to unproven technologies. In an environment defined by change, there is a high risk of failure when piloting new programs and services. The cost of doing business, though, must include a tolerance for trial and error, especially as it relates to the costs of technology. Commercial institutions have long known that relations with customers, personalized outreach, and marketing require portable tools, whether laptops, projectors, cell phones, or advanced mobile devices. Institutions will need to become more comfortable providing individual librarians with current communication technologies if services are to expand and become ubiquitous.

Libraries need to look at all of these variables when deciding which services to offer. In his contribution to RUSA's forum on the future of reference services, Janes (2003) reminds us that each library will need to determine for itself a mix of reference services that best meet the needs of its patrons and its own resources (human, information, financial) ( p. 23). He suggests that libraries must also find ways to articulate the choice of services and consequences of each choice to the user so that the user can decide what service best suits their needs. (Janes, 2003, p. 24) As patrons become accustomed to successful use of intermediary technology outside the library, academic libraries must constantly seek ways to better meet their expectations, including adoption of new technology and service models.

\section{Looking Forward:}

Johnson et al (2010) retain mobile computing on the "near term horizon" in the 2010 Horizon Report in terms of technologies which will have a strong impact on higher education 
within the next 12 months (p. 5). Noting that the majority of higher education students are equipped with some kind of mobile device, and that their opportunities for cellular and WiFi connectivity are becoming more seamless, the devices "from smartphones to netbooks" are quickly becoming "portable tools for productivity, learning, and communication..." (Johnson, et al, 2010, p. 6). A new addition to the Horizon Report, but one which will align closely with mobile computing, is the advance of "simple augmented reality," in which applications for "laptops and smartphones overlay digital information onto the physical world quickly and easily" (Johnson, et al, 2010, p. 6). One example of augmented reality is an iPhone app called Panoramascope which uses the iPhones GPS and compass, along with terrain data from NASA, to create an overlay for geographical features when viewed through the iPhone, providing information for surrounding features, like mountain peaks. Though two to three years out in terms of impact on higher education, it is easy to see how the combination of mobile technology with augmented reality might make for a much more robust virtual reference transaction.

Staley and Malenfant (2010) in the recent report from ACRL, Futures Thinking for Librarians, list a number of the scenarios are either overtly tied to mobile devices and learning, or are implicitly linked to and will benefit from developments in mobile technology. The handheld devices referenced in the "Right here with me" scenario, allow students to discuss assignments with their classmates, faculty, and librarians, and interact with both the physical and digital library collections in new ways (Staley \& Malenfant, 2010, p. 18). Another scenario, "Breaking the textbook monopoly" is one in which "textbooks" evolve into tools which are open access, available online, and created through not only the expertise of the teaching faculty, but also the contributions of the students as they learn (Staley \& Malenfant, 2010, p. 10). This scenario is identified as a medium to high impact opportunity for libraries to add value to the 
curriculum. The provision of "library guide" content through mobile devices would certainly fit into this scenario and is already beginning to happen in some form through the combination of mobile websites, course specific library guides, and mobile devices. One can imagine a work environment in which patrons will be able to move more fluidly between types of content (books, journal articles, reference works, videos, etc.) as well as access help service options anywhere, anytime, from a mobile device. Both will impact libraries, in particular reference departments, because of the expectation that expertise for this "mashup" of information will come from already existing library resources and expertise.

The possibilities for where and when our patrons will be learning are expanding. In an article addressing the impact of "mobile learning" on education, Squire (2009) argues that mobile devices will untether learning from traditional learning spaces such as classrooms. Squire asserts that "Those designing learning environments for a mobile media-enabled world will need to rethink basic assumptions about classroom configurations and learning. Rather than designing for large groups, educators might design for students to be in multiple places in time and place" (Squire, 2009, p. 70). If students are no longer tethered to the traditional learning spaces, then where should the librarian be located?

Perhaps the largest impact that mobile technology will have on libraries will come indirectly through its effects on pedagogy and its "unique capacities for transformative learning experiences" (Squire, 2009, p. 70). The ability for mobile devices to turn locations outside the classroom, or library for that matter, into learning spaces is evident in activities like geo-caching and "citizen journalism," both of which allow the user to interact with and inform other users both synchronously and asynchronously (Squire, 2009, p. 76). Squire encourages us to look at the mobile learning paradigm as one which shifts us to a "multiplicity of places" 
with personalized options for learning, and away from a traditional educational model in which the group learns together in "industrial mode" (Squire, 2009, p. 71). Clearly a model focused on the reference desk model may have less to offer a student who is accustomed to mobile learning.

\section{Conclusion}

The ideal of the ubiquitous library may well be a moving target, as patrons' expectations will probably continue to change as the technology develops. In addition, not all reference librarians agree that mobile technology is the panacea as they work with patrons who are personalizing their spaces both on and off campus. As reference librarians struggle with the issues related to technology, patron expectations, and pedagogy, so the library administrator must deal with the same issues, taking into consideration the challenges of serving patrons in a highly mobile society while still ensuring service models that are reliable, consistent, and sustainable. In addition, long term questions of institutional organization, collection development, and even facility construction and renovation are all impacted by rapidly advances in mobile technology. Far from being a threat, though, mobile technology presents opportunities for librarians to come closer than ever to the ideal of providing service and content to patrons anytime and anywhere. Given the right tools and the right motivation, even a moving target can result in a bullseye. 


\section{References}

2010. "OCLC's Question Point for mobile reference." Searcher 18, no. 3: 42. Library, Information Science \& Technology Abstracts, EBSCOhost (accessed September 27, 2010).

Association of College \& Research Libraries. Research and Planning Review Committee. (2010). 2010 top ten trends in academic libraries: a review of the current literature. College and Research Libraries News, 286 - 292.

Booth, C. (January 01, 2008). Developing Skype-based reference services. Internet Reference Services Quarterly, 13, 147-165.

Booth, C. (2009). Informing Innovation: Tracking Student Interest in Emerging LibraryTechnologies at Ohio University. Chicago: Association of College and Research Libraries, American Library Association.

Connaway, L.S. and T. J. Dickey. (2010). The Digital Information Seeker: Report of theFindings from Selected OCLC, RIN, and JISC User Behaviour Projects. Dublin, OH: OCLC Research.

Glueck, J. (2010, August 13). Moore's Law Hits a Wall: Trouble for Mobile Growth? Retrieved September 1, 2010 from http://venturebeat.com/2010/08/13/moore\%E2\%80\%99s-law-hits-a -wall-trouble-for-mobile-growth/

Hahn, J. (August 15, 2008). Mobile learning for the twenty-first century librarian. Reference Services Review, 36, 3, 272-288.

Hudson, A. (January 01, 2010). Measuring the impact of cultural diversity on desired mobile reference services. Reference Services Review, 38, 2, 299-308.

Janes, J. (2003). What is reference for? Reference Services Review. 31, 1, 22-25. 
Johnson, L., Levine, A., Smith, R., \& Stone, S. (2010). The 2010 Horizon Report. Austin Texas: The New Media Consortium.

Kaske, N. K. (April 01, 2004). The ubiquitous library is here. Portal: Libraries and the Academy, 4, 2, 291-297.

Lippincott, J. K. (May 18, 2010). A mobile future for academic libraries. Reference Services Review, 38, 2, 205-213

Pirani, J.A., and M.C. Sheehan. Spreading the Word: Messaging and Communications in Higher Education-Key Findings (Key Findings). Boulder, CO: EDUCAUSE Center for Applied Research.

Reference and User Services Association [RUSA] (2008). Definitions of Reference. Retrieved July 28, 2010 from http://www.ala.org/ala/mgrps/divs/rusa/resources/guidelines/definitionsreference.cf.

Robinson, K. (2005). Point-of-need customer service: mobile service using wireless technology. Journal of Access Services, 3, 2, 1-14.

Smith, S,D., Salaway, G. and J.B. Caruso. (2009). The ECAR Study of Undergraduate Students and Information Technology, 2009. Boulder, CO: Educause Center for Applied Research (ECAR).

Smith, A. (2010, July 7). Mobile Access 2010. Retrieved September 1, 2010 from Pew Internet \& American Life Project: http://www.pewinternet.org/Reports/2010/Mobile-Access-2010.aspx?r=1

Squire, K. (January 30, 2009). Mobile Media Learning: Multiplicities of Place. On the Horizon, $17,1,70-80$. 
Staley, D., \& Malenfant, K. (2010). Futures thinking for academic librarians: higher education in 2025. Information Services \& Use, 30(1/2), 57-90.

Stein, J. (2010). Call Me!. Time, 175(2), 68. Retrieved September 14, 2010 from Academic Search Premier database.

Steiner, H. (2010). Livening virtual reference with screencasting and screen sharing. Library Hi Tech News, 27(4/5), 9-11.

Ubiquitous (n.d.) In Oxford English Dictionary (OED) Online. Retrieved September 23, 2010 from OED Online: http://dictionary.oed.com.

Walker, J.A. and 1. Jorn. (2009). 21st Century Students: Technology Survey. Retrieved September 25, 2010 from University of Minnesota: www.oit.umn.edu/prod/groups/oit/@pub/@oit/.../oit_content_177146.pdf.

Watstein, S. B., \& Bell, S. J. (August 01, 2008). Is there a future for the reference Desk? A Point-counterpoint Discussion. Reference Librarian, 49, 1, 1-20. 